\title{
Clones, Controversy, and Criminal Law: a Comment on the Proposal for Legislation Governing Assisted Human Reproduction
}

\section{Timothy CaUlfield}

In the past few years there has been a tremendous amount of regulatory conflict and social controversy in the area of reproductive genetics. The Canadian government has recently released a proposal for legislating in this complex arena. Although the proposed Bill contains many positive elements, it is argued that the use of the criminal law as a regulatory mechanism is neither warranted nor appropriate. The author suggests a more flexible and responsive system of moratoriums and licences that would enable review and adjustment to the realities of emerging reproductive technologies is a better approach.
Les dernières années ont vu de très nombreux conflits réglementaires et beaucoup de controverse sociale dans le domaine de la génétique de la reproduction. Le gouvernement canadien vient de déposer un projet de loi visant à légiférer ce domaine très complexe. Bien que le projet de loi contienne de nombreux élements positifs, on peut insister sur le fait que le recours au droit criminel en tant que mécanisme réglementaire n'est ni justifié, ni approprié. L'auteur propose un système plus souple et plus réceptif de moratoires et de permis qui laisse place à la révision et à la modification face aux réalités des nouvelles techniques de reproduction.

\section{TABLE OF CONTENTS}

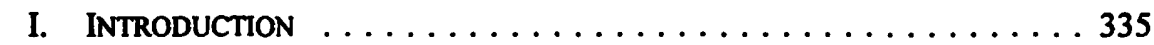

II. FleXIBILITY IS CRITICALly IMPORTANT $\ldots \ldots \ldots \ldots \ldots \ldots \ldots 337$

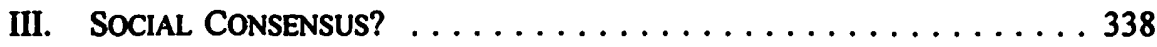

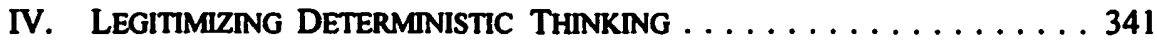

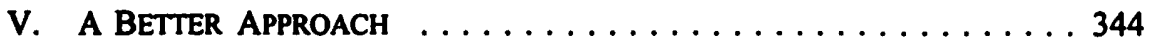

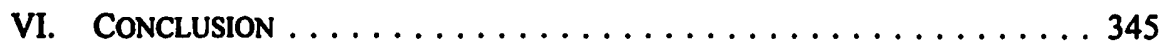

\section{INTRODUCTION}

In the past few years there has been a tremendous amount of scientific activity and social controversy in the area of reproductive genetics. The recent advances that have occurred in the area of stem cell research have sparked an international debate about the regulation of research involving embryos.' There has been growing concern about the

Associate Professor, Faculty of Law and Faculty of Medicine and Dentistry; Research Director, Health Law Institute, University of Alberta. I would like to thank Bartha Maria Knoppers, Alison Harvison-Young, Saradhi Puttagunta, Chantelle Washenfelder, Nina Hawkins, June Ross, and my StemNET colleagues for their assistance and insight, and Genome Prairie and the Alberta Heritage Foundation for Medical Research for research support. Portions of this comment have been modified from my contributions to T. Caulfield \& B. Knoppers, "Don't Make Science a Crime" (20 August 2001) Globe and Mail A9.

1 See, for example, L. Guenin, "Morals and Primordials" (2001) 292 Science 1659; Canadian Institutes of Health Research, Human Stem Cell Research: Opportunities for Health and Ethical Perspectives: A Discussion Paper (Ottawa: Canadian Institutes of Health Research, 2001); U.S., National Institutes of Health, Guidelines for Research Using Human Pluripotent Stem Cells (U.S.A.: National Institutes of Health, 2000); Nuffield Council on Bioethics, Stem Cell Therapies: The Ethical Issues (London: Nuffield Council on Bioethics, 2000); and T. Friend, "The Stem Cell Hard Sell" USA Today (17 July 2001) 6D. 
possible use of genetic selection and enhancement techniques. ${ }^{2}$ And, of course, the spectre of human reproductive cloning has generated significant media and government attention. ${ }^{3}$ Indeed, with each passing day the issues associated with the science and practice of reproductive genetics become more intense and complex. Canada has no laws specifically designed to address the myriad concerns. However, this may soon change.

In May of this year, the federal government released a Proposal for Legislation Governing Assisted Human Reproduction. ${ }^{4}$ The Proposal has been distributed as a mere draft in order stimulate further commentary. It is anticipated that a final version will be introduced in early 2002.5 As it currently stands, the Proposal sets out a regulatory framework that would criminally ban some activities, such as reproductive cloning and the creation of embryos for research purposes, and simply regulate others. ${ }^{6}$ The importance of this legislation cannot be overestimated. This law will have an impact on researchers, the direction of the biotechnology industry, and the reproductive options of Canadians. Most important, however, the law will have tremendous symbolic significance as it will stand as Parliament's first formal statement on a range of controversial issues related to the emerging genetic and biotechnology revolution.

Despite the criticisms to follow, it is important to highlight that the legislation has many positive attributes. It sets the framework for a comprehensive regulatory body that

M. Frankel \& A. Chapman, "Facing Inheritable Genetic Modifications" (2001) 292 Science 1303; E. Parens \& E. Juengst, "Inadvertently Crossing the Germ Line" (2001) 292 Science 397; M. Damewood, "Ethical Implications of a New Application of Preimplantation Diagnosis" (2001) 285 J. Am. Med. Assoc. 3143.

3 See, for example, L. Rogers, "Secretive Preparing to Clone First Human Baby" Edmonton Journal (18 February 2001) A2; P. Delves Broughton, "Canadian Cult Says it Will Clone Couple's Dead Girl" Edmonton Journal (3 January 2001) A1; M. Higgins, "Scientists Plan Human Clones" National Post (10 March 2001) A1; See also S. Delaney, "Scientists Prepare to Clone a Human: Experiment Aims to Help Infertile Couples" The Washington Post (10 March 2001) A16; M. Talbot, "A Desire to Duplicate" The New York Times Magazine (4 February 2001) 40; and N. Gibbs, "Wanting A Clone" Time 157:7 (19 February 2001) 43; R. Weiss, "Furor sparked over scientists' scheme to clone humans" Edmonton Journal (8 August 2001) Al; Editorials, "Cloning babies is outrageous" Edmonton Journal (11 August 2001) A14; C. Lord, "Cloning dangers draw waming" Edmonton Journal (12 August 2001) Al. Health Canada, Proposal for Legislation Governing Assisted Human Reproduction: Draft Legislation (May 2001), online: Health Canada <http://www.hc-sc.gc.ca/english/reproduction/legislation.pdf (date accessed: 26 July 2001) [hereinafter Proposal].

s Health Canada, “Assisted Human Reproduction: Frequently Asked Questions" (May 2001), online: Health Canada <http://www.hc-sc.gc.ca/english/archives/releases/2001/2001_44ebk3.htm> (date accessed: 26 July 2001) [hereinafter "Frequently Asked Questions"]. At question 7 the release indicates, "The Minister has asked the Standing Committee to provide him with a report by the end of January 2002. It would then be possible to table legislation in Parliament and a regulatory body could be established soon after."

- See section 3, supra note 4. Specifically, the law will criminally ban: cloning human beings, germ line genetic alteration, developing an embryo outside a woman's womb beyond the accepted 14 day limit, creating human embryos solely for research purposes, creating an embryo from another embryo or fetus, transplanting reproductive material from animals into humans, using human reproductive material previously transplanted into an animal, gender preference or sex selection, and a number of activities when done for the purpose of commercial gain. See generally Health Canada, Proposal for Legislation Governing Assisted Human Reproduction: An Overview (May 2001) at 4-7, online: Health Canada <http://www.hc-sc.gc.ca/english/reproduction/repro_over.pdf> [hereinafter "Overview"]. 
would cover clinical and research activities in both the public and private spheres. The recommended licensing and reporting schemes would facilitate quality control and encourage the development of national standards. Not to mention that the law, particularly the preamble, emphasizes important ethical principles that should continue to inform policy development in this context. ${ }^{7}$

The ongoing consultative process is also worthwhile. Canada is one of the few countries in the Western world not to have specific legislation in this area, and it has been eight years since the Royal Commission on New Reproductive Technologies issued its final report. ${ }^{8}$ Nevertheless, this is the federal government's first foray into a field that will undoubtedly continue to create new and controversial challenges for human society. So while many Canadians may be frustrated by the ongoing discussions surrounding the law,' it is critically important that we get this right.

This brief comment provides analysis of the weakest aspect of the Proposed law - the use of criminal prohibitions to ban specific activities.

\section{Flexibility is Critically Important}

Like the first version of this legislation, Bill $C-47,{ }^{10}$ the federal government has chosen to use criminal prohibitions to regulate many of the most controversial reproductive practices." Yes, a strong oversight scheme is clearly needed, and there are currently a number of reproductive technologies and research activities that should not be allowed. But specific criminal prohibitions are not necessary, nor are they the best way to regulate in this area. Criminal laws are blunt, inflexible, and require a good deal of time and political energy to change - terminal characteristics in an area as dynamic and controversial as reproductive technologies.

1 For example, the Preamble notes, inter alia, the need to promote the "best interests of children" and the "principle of free and informed consent" and recognizes the "health and ethical concerns inherent in the trade in the reproductive capacities of women and men." Proposal, supra note 4.

- Canada, Proceed With Care: Final Report of the Royal Commission on New Reproductive Technologies, vols. 1, 2 (Ottawa: Supply and Services Canada, 1993). See also P. Baird, "Proceed with Care: New Reproductive Technologies and the Need for Boundaries" (1995) 12 J. A. R. G. 491.

9 See V. Lawton, "Ottawa ready to unveil cloning bill -Draft would regulate reproductive practices" The Toronto Star (2 May 2001) A6.

Bill C-47, An Act respecting human reproduction technologies and commercial transactions relating to human reproduction, 2d Sess., 35th Parl., 1996 was dropped from the federal agenda when the 1997 federal clection was called.

1I At the time, the use of criminal prohibitions was criticized by myself and others. See T. Caulfield, M. Hirtle \& S. LeBris, "NRTs: Is Criminalization the Solution for Canada?" (1997) 18 Health L. Can. 3; B. Dickens, "Do Not Criminalize New Reproductive Technologies" (1996) 17 Policy Options 11; and A. Harvison-Young \& A. Wasunna, "Wrestling with the Limits of Law: Regulating Reproductive Technologies" (1998) 6 Health L.J. 239 at 276: "[C]riminal law, in itself, is an inadequate tool with which to address the complex issues raised by NRTs. It is a blunt instrument that is ill-suited to both the nuances and subtleties that pervade the area, and to the realities of rapid change." 
Some may feel that Canada needs strong prohibitions due to the rapid and seemingly uncontrollable pace of scientific advances. ${ }^{12}$ In fact, the rapid advances we are witnessing in this area support arguments against, and not for, criminal laws. Science has a way of creating new and unique social issues, while, at the same time, making old ones seem misplaced or irrelevant. ${ }^{13}$ Indeed, much has changed since the 1993 publication of the Royal Commission on New Reproductive Technologies. We have, for example, mapped the human genome, cloned a variety of mammals, developed new assisted reproductive technologies, ${ }^{14}$ and witnessed ground breaking advances in the area of stem cell research. ${ }^{15}$ Bill C-47 was drafted without knowledge of many of these issues, and, as such, the language seems awkward and outdated. How will the prohibitions in this proposed law be viewed a mere four years from now? ${ }^{16}$

Crafting enduring regulations in such a fluid environment is a tremendous challenge. But one thing seems clear - rigid prohibitions are not the answer. Canada needs a legal structure that can respond to scientific and social changes. Amending the current list of prohibitions, either to accommodate a new concern or a new scientific advance, would require an act of Parliament - hardly the responsive process needed for this area.

\section{SOCiAl CONSENSUS?}

Complicating matters further is the fact that there is still no agreement regarding the appropriateness of many of the suggested prohibitions. Criminal law should be reserved for areas where there is a high degree of social consensus." One of the information documents that accompanied the Proposal suggested that " $t]$ here is a broad consensus that the activities that would be banned under the proposed legislation are not acceptable in Canada." 18 This statement simply is not true. ${ }^{19}$ In fact, there is still a great deal of

For example, in the press release announcing the Proposal Minister Rock states: "[I]n an era of rapid scientific advances it is imperative that the interests of all Canadians, especially their health and safety, be protected." Health Canada, News Release, "Rock Launches Review of Draft Legislation on Assisted Human Reproduction to Ban Human Cloning and Regulate Related Research" (3 May 2001), online:HealthCanada<http://www.hc-sc.gc.ca/english/archives/releases/2001/2001_44e.htm> (date accessed: 30 July 2001).

I have noted this elsewhere. See T. Caulfield, "Science, the Law and Stem-Cell Research" Folio 38:11 (9 February 2001) 5.

For example, see Reuters, "Scientific Discovery Raises Possibility of Human Reproduction Without Sperm" Globe and Mail (11 July 2001) A9.

G. Vogel, "Breakthrough of the Year: Capturing the Promise of Youth" (1999) 286 Science 2238. In fact, by putting a mandatory five-year review into the legislation, the federal govemment seems to be implicitly recognizing the potential obsolescence of the existing Proposal. Supra note 4, s. 42. See Canada, The Criminal Law in Canadian Society (Ottawa: Government of Canada, 1982); and Law Reform Commission of Canada, Our Criminal Law (Ottawa: Law Reform Commission of Canada, 1976) at 33 where it is recommended that "in the future our lawmakers should also exercise this restraint in creating new offences. We recommend that this restraint be exercised both as regards 'real' crimes and regulatory offences."

18 "Frequently Asked Questions," supra note 5 at question 9.

19 The lack of consensus was noted by A. Harvison-Young \& A. Wasunna in relation to Bill C-47. In noting that the federal government failed to understand the extent of the social controversy surrounding these technoldgies the authors stated, "Neither the Final Report [on New Reproductive Technologies] nor the government responses to it appear to have grappled with this issue, and to the 
national and international debate around many of the prohibited activities, including the appropriateness of creating embryos for research purposes,$^{20}$ germ line therapy, and human cloning. ${ }^{21}$

For example, though Canadians oppose reproductive cloning ${ }^{22}$ - that is, using cloning technology to create new humans - there is some evidence that most are comfortable with the idea of therapeutic cloning. A recent survey conducted by PricewaterhouseCoopers found that over three-quarters of Canadians believed cloning human tissue for medical purposes, also known as "therapeutic cloning," was acceptable. ${ }^{23}$ Research in other jurisdictions has also found no strong opposition to the use of this technique. ${ }^{24}$

extent they have, they have done so by seriously understating the extent of controversy, or, to put it another way, by overstating the degree of public consensus." Supra note 11 at 245.

See R. Winston, "Embryonic Stem Cell Research: The Case For..." (2001) 7 Nature Medicine 396; M. Antoniou, "Embryonic Stem Cell Research: The Case Against..." (2001) 7 Nature Medicine 397; and J. Robertson, "Human Embryonic Stem Cell Research: Ethical and Legal Issues" (2001) 2 Nature Reviews Genetics 74. See also Associated Press, "Embryos Created to Provide Valuable Stem Cells for Research" Edmonton Journal (12 July 2001) A2, where it is reported that scientist- created embryos from donated sperm and eggs are used specifically for the purpose of research. It is reported that those involved believe that because the donors are consenting to a specific project, "it's cleaner [ethically] than using leftover embryos... There's no question as to what you're going to do with these embryos."

For example, see generally P. Lauritzen, ed., Cloning and the Future of Human Embryo Research (New York: Oxford University Press, 2001); B. MacKinnon, ed., Human Cloning: Science, Ethics and Public Policy (Chicago: University of Illinois Press, 2000); G. McGee, ed., The Human Cloning Debate (Berkeley: Berkeley Hills Books, 2000); and M. Nussbaum \& C. Sunstein, eds., Clones and Clones: Facts and Fantasies About Human Cloning (New York: W.W. Norton and Company, 1998). See E. Eisiedel, "Cloning and Its Discontent: A Canadian Perspective" (2000) 18 Nature Biotechnology 943 . However, see ibid., for a brief survey of dissenting views from the academic community on the ethical concerns around cloning.

See PricewaterhouseCoopers, "Canadians Support Cloning of Human Organs, Survey Says," online: PricewaterhouseCoopers <http://www.pwcglobal.com/extweb/ncpressrelease.nsf/DocID/ 9102EE7D067B9C28852569F8007563FA> (date accessed: 30 July 2001); See also Canadian Press, "Canadians Support Cloning of Human Organs, New Survey Suggests" Canadian Press, (2 February 2001), online: Dow Jones Interactive <http://nrstglp.djnr.com/cgi-bin/DJInteractive?cgi= WEB_FLAT_PAGE\&page $=$ wrapper/index\&NRAUTOLOG $=01$ UEPC19iwm TmN4xJLbQSOBIEyrf IA\&NRLBRedirect=nrstg2s\&user_bounced=1\&entry_point=1> (date accessed: 30 July 2001); and H. Scoffield, "Canadians Favour Limited Use of Clones for Emergencies Only, Survey Finds" Globe and Mail (16 June 2000) A2, where it is reported that "more than 80 per cent of Canadians said they believed cloning of human skin or other organs such as hearts and livers was acceptable."

For example, see Medicine and Society Program, the Wellcome Trust, Public Perspectives on Human Cloning: A Social Research Study (London: The Wellcome Trust, 1998) at 3.1-3.6; and Institut National de la Recherche Agronomique (Europe), Eurobarometer 52.1: The Europeans and Biotechnology (Report for the European Commission's Directorate-General for Research, 15 March 2000) at 32, online: European Union <http://europa.eu.int/comm/research/pdf/eurobarometer-en.pdfs (date accessed: 30 July 2001 ). 
Moreover, there is no agreement within the international community on how therapeutic cloning should be addressed. ${ }^{25}$ Though a number of countries have moved to prohibit the practice, the UK has decided to allow research on therapeutic cloning to continue. ${ }^{26}$ Recently the Royal Society in London, citing the therapeutic potential of cloned tissue, also issued a policy statement supporting the practice. ${ }^{27}$ The proposed Canadian law would make therapeutic cloning a criminal offence. ${ }^{28}$

Not only is there no consensus now, but attitudes will undoubtedly change as new technologies and controversies emerge. Indeed, when using the idea of social consensus as a justification for a ban, it is worth remembering that the public's attitude toward a number of the prohibited activities may shift substantially in a relatively short amount of time. Research on cadavers was once considered an affront to human dignity. The announcement of Louise Brown, the first "test tube" baby, was met with a degree of repulsion. Heart transplants were considered unnatural. And there were even calls for criminal prohibitions to stop the practice of sperm donation. ${ }^{29}$

The perceived health care benefits of a given activity play an important role in the evolution of public policy and public attitudes. Scientific advances can have a profound impact even on strongly held views. A recent poll conducted in the United States found that most Americans now support using federal money for embryonic stem cell research..$^{30}$ The potential benefits associated with research in this area has even persuaded

2s See, for example, J. Savulescu, "The ethics of cloning and creating embryonic stem cells as a source of tissue for transplantation : time to change the law in Australia" (2000) 30 Aust. N.Z. J. Med. 492; A. Regalado, "Bush Administration Says it Opposes Cloning of Human Embryos for Research" The Wall Street Journal (21 June 2001) A4; A. Handelsblat, "German Group Backs Stem Cell Research On Embryos" The Wall Street Journal Europe (4 May 2001) 2.

G. Vogel, "British Parliament Approves New Rules" (2001) 291 Science 23; and R. Winston, supra note 20.

27 The Royal Society, "Stem Cell Research: Second Update" Policy Document 9/01 (June 2001), online: The Royal Society <www.royalsoc.ac.uk/files/statfiles/keywords-148.txt> (Date accessed: 30 July 2001). See also "Stem Cell Research and Therapeutic Cloning" Policy Document $12 / 00$ (November 2000), online: The Royal Society <www. royalsoc.ac.uk/policy/stem_cell_ researchl.htm> (date accessed: 30 July 2001). For a discussion of scientific potential of therapeutic cloning see A. Colman \& A. Kind, "Therapeutic Cloning: Concepts and Practicalities" (2000) 18 Trends in Biotechnology 192 at 195 . The authors conclude:

Therapeutic cloning presents a tantalizing new approach to the problem of diseased tissue replacement. Although many technical hurdles remain concerning the validation of ES-like lines, poor nuclear-transfer efficiencies, and the generation and expansion of specific stem-cell populations, it is an exciting new addition to the promising field of stem-cell culture, differentiation, and therapy.

"Overview," supra note 6 at 5, where it is stated that "[t]herapeutic cloning' would be prohibited in Canada."

L.B. Andrews \& N. Elster, “Regulating Reproductive Technologies” (2000) 21 J. of Leg. Med. 35. D. Caldwell, "The Surprising Politics of Stem Cells" ABC News/Beliefnet Poll, online: Beliefnet <http:/www.beliefnet.com/story/82/story_8276_1.html> (date accessed: 30 July 2001). See also Associated Press, "Poll Finds Stem Cell Research Supported in US By 2-1 Margin" Dow Jones Business News, (26 June 2001), online: Dow Jones Interactive <http://nrstg2p.djnr.com/ cgi-bin/DJInteractive?cgi=WEB_FLAT_PAGE\&page=wrapper/index\&NRAUTOLOG $=01$ UEPC $9 \mathrm{i}$ wmTmN4xJLbQS0BIEyrflA\&NRLBRedirect-nrstg2p\&entry_point=1> (date accessed: 15 June 2001). 
most Catholics and Republicans, groups traditionally opposed to research involving embryos, to support work on embryonic stem cells.

Finally, policy makers must be sensitive to the complicated nature of the public's reaction to biotechnology. ${ }^{31}$ For instance, the public's strong reaction to a specific technology, such as cloning, may be more an indication of a general unease "over the relationship between technology and society" 32 than a clear opposition to one scientific innovation. Simply banning a given technology will do little to help explore this ambivalence and to respectfully engage the public in an ongoing dialogue about biotechnology.

Although the federal government should not craft laws in response to the results of survey data, a research methodology with inherent flaws, it is clear that the federal government cannot justify many of the prohibitions, such as the one against therapeutic cloning, on the basis of a strong social consensus. More important, however, the government needs to recognize that both the dynamic nature of the science in this area and the inevitably swift evolution of social norms will continue to make it difficult for policy makers to justify prohibitions on social consensus alone. As noted by HarvisonYoung and Wasunna in their critique of Bill C-47: "Associated with rapid technological change is the accompanying and inevitable change in public attitudes, making it difficult to rest the legitimacy of the law on any degree of social consensus." ${ }^{33}$ Canada's regulatory framework should be capable of reflecting the likely shift in social attitudes about reproductive technologies - whether the shift is toward a more permissive approach or toward a call for more restrictions.

\section{LEgItimizing Deterministic THINKING}

Another problem with the Proposal is that the stated justifications for a number of the prohibitions are not particularly well thought out. Worse still, because they are associated with the federal government's most potent regulatory tool, the criminal law, they have the potential to formally and powerfully legitimize inappropriate and scientifically inaccurate conceptions of human genetics.

The justification for the ban on human cloning ${ }^{34}$ is provided in the Overview document that accompanies the Proposal. ${ }^{35}$ The Overview defines cloning as "intentionally creating

For a discussion of the impact of culture and the media on perceptions of genetics and biotechnology see U. Fleising, "Genetic essentialism, mana, and the meaning of DNA" (2001) 20 New Genetics and Society 43; and A. Peterson, "Biofantasies: genetics and medicine in the print news media" (2001) 52 Soc. Sci. \& Med. 1255.

E. Eisiedel, supra note 22 at 944 . As noted by Dorothy Nelkin and Susan Lindee, the debate over technologies like human cloning "provide[s] a window on popular beliefs about human nature and the social order, on public fears of science and its power in society, and on concerns about the human future in the biotechnology age." Quoted in ibid. Supra note 11 at 276.

Section 3(1)(a) states that "[n]o person shall knowingly create or participate in the creation of a human clone or transplant or participate in the transplantation of a human clone into a human being." Proposal, supra note 4. 
identical copies of an individual." ${ }^{36}$ The document then sets out the justification for the ban:

Human cloning would be banned because it treats human beings as though they were objects and does not respect the individuality of human beings. The health of human clones could be at risk, since animal cloning is associated with frequent miscarriages, malformations and early deaths. Also, there would likely be psychological burdens on a cloned child, who might be viewed as a replica of another person rather than an individual in his/her own right. ${ }^{37}$

There are a number of sound arguments against human cloning, including health and safety uncertainties, research ethics issues, and the concern that human cloning would facilitate genetic enhancement. Moreover, the practical uses of reproductive cloning are probably quite limited. As such, a moratorium on reproductive cloning seems entirely appropriate. However, the federal government's explanations for the ban are inconsistent, scientifically inaccurate, and support the current trend toward genetic determinism.

At some level both the arguments against human cloning and the government's definition of a clone are based, explicitly or implicitly, on a belief that our future lies in our genes and that our sense of self is necessarily tied to our genetic heritage. This deterministic vision of genetics is clearly wrong. In fact, there are very few human conditions, be they behavioral or physical, that can be explained solely through genetics. If we have gained anything from the tremendous advances that have occurred in the area of human genetics, it is a greater appreciation for the incredible complexity of the interactions between genes and other genes and between genes and the environment. As noted by Bonnie Steinbock, the objections that cloning is a threat to autonomy and individuality are "based on a fallacious assumption: ... if you know what your genome is, you will know what your choices, and hence your life, will be. This is the fallacy of genetic determinism.... To put it bluntly, we are not our genes, and our genes do not determine what we are or will be."38 Clones would not be "identical copies" of the source, the future of the clone would not be compromised simply because it shares a genome, and any "psychological burden" that would be placed on a cloned child would

Ibid. at 4.

lbid.

B. Steinbock, "Cloning Human Beings: Sorting Through the Ethical Issues" in B. Mackinnon, ed., Human Cloning: Science, Ethics and Public Policy (Chicago: University of Illinois Press, 2000) 68 at 72. Many other commentators have noted the genetic determinism problem that exists in emerging cloning laws. See, for example, R.C. Lewontin, "The Confusion over Cloning" The New York Review of Books (23 October 1997), online: The New York Review of Books <http:/www.nybooks.com/ nyrev/WWWarchdisplay.cgi?19971023018R> (date accessed: 30 July 2001); D. Beyleveld \& R. Brownsword, "Human Dignity, Human Rights, and Human Genetics" (1998) 61 Mod. L. Rev. 661; J. Savulescu, "Should We Clone Human Beings? Cloning as a Source of Tissue for Transplantation" (1999) 25 J. Med. Ethics 87; and A. Buchanan et al., From Chance to Choice: Genetics and Justice (Cambridge: Cambridge University Press, 2000). I have discussed this issue elsewhere. See T. Caulfield, "Cloning and Genetic Determinism: A Call for Consistency" (2001) 19 Nature Biotechnology 403; and T. Caulfield, "Underwhelmed: Hyperbole, Regulatory Policy and the Genetic Revolution" (2000) 45 McGill L.J. 437. As an example of a commentator who supports the contrary view see R. Williamson, "Human Reproductive Cloning is Unethical Because it Undermines Autonomy" (1999) 25 J. Med. Ethics 96. 
be a direct result of the parents' mistaken belief in genetic determinism and not as a result of the cloning technology.

This is not to say that cloning is a good idea. As the Overview document notes, there are real health and safety issues associated with the technology. So if I agree that reproductive cloning is currently a bad idea, why do I view these poor justifications as problematic? In other words, who cares why the ban is implemented so long as it is implemented? As recently argued by Svante Paabo, the "greatest danger" associated with the genetic revolution is, arguably, the "sharp shift toward an almost completely genetic view of ourselves." ${ }^{39}$ If one takes the government's explicit justifications as sincere, then the law formally legitimizes this shift toward a deterministic perspective. Cloning should be banned, the government argues, because it allows the creation of identical human beings, something that does not respect the individuality of human beings. ${ }^{40}$

The goal of government in this context should be to protect the public from genuine health and safety issues, which undeniably exist, and to promote an informed discourse on the scientific, philosophical, and health care issues surrounding the technology. ${ }^{41}$ Indeed, this latter goal seems critically important in the fight against the emergence of a deterministic ethos. While the proposed ban will address the health and safety concerns, it may also, ironically, promote and engrain a social attitude that is more problematic than the use of cloning technology.

Finally, the use of health and safety concerns as a primary rationale for a number of the prohibitions also warrants comment. Though health and safety concerns provide clear justifications for regulating an area, they seem unusual reasons for specific criminal prohibitions in this context. Are we to presume, for example, that if scientific advances remove the health and safety concerns associated with therapeutic cloning the activity would no longer need to be criminalized? If so, why the rigid prohibition? Would not the use of criminal prohibitions make it more difficult to do research on the health and safety issues? ${ }^{42}$

S. Paabo, "The Human Genome and Our View of Ourselves" (2001) 291 Science 1219 at 1220.

One might argue, as is done in the US National Bioethics Advisory Commission's report on cloning, that in a world where people believe in genetic determinism, a clone may simply believe that his or her uniqueness and autonomy are limited. See US National Bioethics Advisory Commission, Cloning Human Beings: Report and Recommendations of the National Bioethics Advisory Commission, vols. I, 2 (Maryland: National Bioethics Advisory Council, 1997). But, as I note elsewhere, "if the problem is a misplaced belief in the power of genes and not the use of the technology, governments seem to be aiming their regulatory powers at the wrong target. Indeed, the passing of a law that, on the surface, legitimates the deterministic misperception may, in the long run, do more harm than the technology." T. Caulfield, supra note 38 at 403.

4) I am not arguing that health and safety issues are the only justification for regulating in this area. However, given the degree of controversy that still surrounds the other justifications (for example, that cloning is an affront to human dignity, see D. Beyleveld, supra note 38), health and safety remains the clearest rationale at this time.

42 There are, of course, other problems with the use of criminal law in this context. It has been frequently noted that because criminal prohibitions are a blunt regulatory instrument, they have the potential to cast a chill over broad areas of research. See, for example, S. Wolf, "Ban Cloning? Why NBAC Is Wrong" in G. McGee, ed., The Human Cloning Debate (Berkeley: Berkeley Hills Books, 2000) 118; A. Harvison-Young, supra note 11; and, see generally T. Caulfield, A. Wasunna \& M. 


\section{A BETTER APPROACH}

There is an alternate, non-prohibition model that would allow the federal government to achieve its stated policy goals and produce a more flexible and effective regulatory environment.

The federal government could create a regulatory body empowered to both issue licences for a defined set of activities (similar to what is currently proposed) ${ }^{43}$ and produce, modify, and monitor a "moratorium list." This list would contain the activities which, at this time, should not be allowed (e.g., reproductive cloning). One of the primary advantages of such an approach is that the list could be amended and interpreted by the regulatory body instead of by Parliament. In addition, the law could set out a specific consultation process, thereby facilitating and promoting an ongoing, interdisciplinary dialogue on these important issues. By doing so, the regulatory body could respond to the issues associated with reproductive genetics in a more precise and flexible manner.

Of course, the issue of federal/provincial jurisdiction is one of the unspoken justifications for the criminal prohibitions, and may, in fact, be the primary political reason for the proposed scheme. Section 91(27) of the Constitution Act, $1867^{44}$ gives the federal government the power to enact criminal laws, while the Constitution has been interpreted in the caselaw as giving the provinces the power to enact laws in the area of health. ${ }^{45}$ As a result of this division of powers, the federal government may feel "criminal like" prohibitions are necessary in order to secure jurisdiction. In one of the information documents that was distributed with the Proposal, it is stated that " $[t]$ he draft legislation is founded upon the federal responsibility for criminal law, as is other federal health protection legislation such as the Food and Drugs Act and the Tobacco Act." ${ }^{146}$

There seems little doubt that the federal government can use the criminal law power to enact such legislation. However, this does not mean that the federal government must necessarily criminally ban the listed activities as it does in the Proposal. The courts have generally interpreted s. 91(27) of the Constitution very liberally. ${ }^{47}$ For example, in $R J R$ MacDonald Inc. v. Canada the Supreme Court of Canada stated:

The scope of the federal power to create criminal legislation with respect to health matters is broad, and is circumscribed only by the requirements that the legislation must contain a prohibition accompanied by a penal sanction and must be directed at a legitimate public health evil. ${ }^{48}$

Hirtle, "Regulating the Genetic Revolution" (1999) 5 Molecular Medicine Today 198.

Proposal, supra note 4.

Constitution Act, 1867 (U.K.), 30 \& 31 Vict., c.3, reprinted in R.S.C. 1985, App. Il, No. 5 [hereinafter Constitution].

See P.W. Hogg, Constitutional Law of Canada, student ed. (Scarborough, Ontario: Carswell, 1999) at 454.

"Frequently Asked Questions," supra note 5 at question 2.

Constitution, supra note 44.

RJR-MacDonald Inc. v. Canada, [1995] 3 S.C.R. 199 at 246, cited in M. Jackman, "Constitutional Jurisdiction Over Health in Canada" (2000) 8 Health L.J. 95 at 101. See also $R$ v. Hydro-Quebec, [1997] 3 S.C.R. 213 thereinafter Hydro-Quebec]; P. Healy, "Statutory Prohibitions and the 
Though the use of clear prohibitions probably helps ensure jurisdiction, the recent case law seems to give the federal government a great deal of latitude to enact legislation based on the criminal law power. ${ }^{49}$ So long as the regulatory scheme has criminal prohibitions and is aimed at a legitimate public health concern, there is a supportable argument that the federal government will retain jurisdiction. ${ }^{50}$

In the scheme I suggest, the criminal prohibitions would be triggered if an individual breached the terms of a licence or undertook an activity on the "moratorium list." One of the dominant themes of the legislation would still be to prohibit certain activities, but the definition of the activities to be prohibited would be more responsive to the reality of genetics and reproductive technologies. In Hydro-Quebec, a case addressing the constitutionality of environmental regulations, La Forest J., writing for the majority, was sympathetic to the idea that a degree of regulatory flexibility may be required in order to achieve the legitimate goals of legislation that is based on the federal criminal law power. As nicely summarized in the head note to the case: "Broad wording is unavoidable in environmental protection legislation because of the breadth and complexity of the subject. The effect of requiring greater precision would be to frustrate the legislature in its attempt to protect the public against the dangers flowing from pollution."sl The same can certainly be said about legislation in the area of genetics and reproductive technologies. Indeed, one could argue that the only way to meaningfully achieve the objectives of the Proposal, and to achieve any degree of real precision, is to create a scheme that is more flexible and responsive. Using the suggested moratorium list, instead of straight criminal prohibitions, would allow for maximum flexibility, encourage ongoing consultation, require only minor modifications to the current proposal, and create a framework capable of having long-term relevance.

\section{Conclusion}

Given the controversial nature of this topic and the enduring lack of social consensus, some degree of compromise is inevitable. It will be impossible for the government to craft a law that will make all the stakeholders happy. The federal government must move forward, and this Proposal has many useful attributes. However, the drawbacks associated with criminal prohibitions in this context are so clear and acute that a reconsideration of legal instruments is essential. Yes, constitutional issues remain. Nevertheless, the government should not let this constitutional uncertainty force the creation of a regulatory framework that is destined to fail. If the government is going to achieve the laudable goal of meaningfully regulating the area of reproductive technologies, it must move away from inflexible and overreaching criminal prohibitions.

Regulation of New Reproductive Technologies under Federal law in Canada" (1995) 40 McGill L.J. 905; R. Mykitiuk \& A. Wallrap, "Regulating Reproductive Technologies in Canada" in J. Downie \& T. Caulfield, eds., Canadian Health Law and Policy (Toronto: Butterworths, 1999); and T. Caulfield, M. Hirtle \& S. LeBris, supra note 11. the government's authority to use criminal law in this context. approach to public health issues under section 91(27), the decision significantly expands the potential for federal reliance on the criminal law power in the area of health." Supra note 48 at 102. 